\title{
Pentingnya Sistem Pengendalian Manajemen dalam Pengelolaan Usaha Kecil dan Menengah di Kabupaten Banyumas, Jawa Tengah
}

\author{
Eko Suyono \\ Fakultas Ekonomi dan Bisnis, Universitas Jenderal Soedirman \\ ekyo75@yahoo.com
}

\begin{abstract}
This study aims to analyze the awareness of small and medium enterprises (SMEs) on the importance of applying management control system variabels that include strategic planning, decision making, and evaluation and control in managing SMEs. By determining the criteria of certain company size in the process of sampling selection, this study ended up with 55 SMEs in Banyumas as a sample. This study employs both qualitative anad quantitative approaches where the questionnaires distribution and interviews were conducted in October and November 2017. By using a descriptive analysis the findings shows that the owners of SMEs in Banyumas have high awareness on the importance of implementing strategic planning, decision making, and evaluation and control to manage their business. However, there are several weaknesses faced by SMEs to do so, for instance, low understanding on those issues due to low of the education level of the owners of SMEs and limited resources. It is important for Banyumas local government to address these issues so the SMEs will develop well in supporting the local economy.
\end{abstract}

Keywords: management control system, strategic planning, decision making, evaluation and control

\begin{abstract}
ABSTRAK
Penelitian ini bertujuan untuk menganalisis kesadaran pemilik/pengelola usaha kecil dan menengah (UKM) terhadap pentingnya penerapan sistem pengendalian manajemen yang meliputi perencanaan strategis, pengambilan keputusan, dan evaluasi dan pengendalian dalam pengelolaan UKM. Dengan menentukan kriteria ukuran perusahaan tertentu dalam proses pemilihan sampel, penelitian ini mendapatkan 55 UKM di Banyumas sebagai sampel. Penelitian ini menggunakan pendekatan kuantitatif dan kualitatif dimana penyebaran kuesioner dan wawancara dilakukan pada bulan Oktober dan November 2017. Dengan menggunakan analisis deskriptif, temuan penelitian ini menunjukkan bahwa pemilik UKM di Banyumas memiliki kesadaran tinggi mengenai pentingnya menerapkan perencanaan strategis, pengambilan keputusan, dan evaluasi dan pengendalian untuk mengelola bisnis mereka. Namun, ada beberapa kelemahan yang dihadapi UKM untuk melakukannya seperti rendahnya pemahaman terhadap isu-isu tersebut karena rendahnya tingkat pendidikan pemilik UKM dan sumber daya yang terbatas. Menjadi penting bagi pemerintah daerah Banyumas untuk menangani isu - isu ini sehingga UKM akan berkembang dengan baik dalam mendukung perekonomian lokal.

Kata Kunci: manajemen strategis, perencanaan strategis, pengambilan keputusan, proses pengendalian
\end{abstract}




\section{PENDAHULUAN}

Selama beberapa dasawarsa terakhir banyak usaha kecil dan menengah yang bergerak dalam bidang perdagangan, manufaktur, rumah makan, dan sebagainya menghadapi perubahan yang sangat dramatis dalam usaha mereka karena perubahan lingkungan bisnis yang semakin dinamis. Hal ini terjadi karena era pasar bebas yang menyebabkan masuknya bisnis asing dan juga berkembangnya beberapa usaha modern seperti super-market, mini-market, industri, dan sebagainya. Kondisi ini menyebabkan UKM berada pada tingkat persaingan yang sangat ketat karena regulasi yang memungkinkan berkembangnya usaha modern bahkan yang berasal dari luar negeri. Seringkali regulasi ini tidak seiring dengan regulasi pemerintah yang bermaksud melindungi UKM yang umumnya merupakan usaha masyarakat pribumi yang sudah berjalan dalam periode waktu yang panjang.

UKM di Provinsi Jawa Tengah sesuai dengan data dari Dinas Koperasi, Usaha Kecil dan Menengah (DINKOPUKM) Jawa Tengah sampai akhir Triwulan IV 2016 berjumlah sebanyak 115.751 unit UKM aktif dan berkontribusi menyediakan sebanyak 791.767 lapangan kerja. Potensi UKM yang begitu besar masih banyak terkendala oleh kelemahan-kelemahan yang dihadapi UKM dibandingkan dengan bisnis modern, seperti: keterbatasan modal, keterbatasan akses terhadap sumber-sumber modal, pendidikan SDM yang relatif rendah, kurangnya jejaring usaha, dan sebagainya (Suyono dkk., 2016).

Salah satu upaya yang bisa dilakukan oleh UKM adalah dengan mengelola informasi bisnis baik keuangan maupun non keuangan secara profesional karena kedua jenis informasi tersebut merupakan salah satu sistem informasi manajemen penting yang harus dimanfaatkan oleh Usaha Kecil Menengah untuk mendapatkan competitive advantage (Hopper dkk., 1999; Regondola, 2017). Disisi lain, dalam memberikan produk atau layanan kepada para pelanggan UKM juga harus mulai memperhatikan isu kepuasan pelanggan supaya produk atau jasa yang diberikan bisa lebih bersaing dengan usaha modern. UKM juga perlu mulai mengadopsi dan mengembangkan sistem industri dan berinvestasi pada teknologi baru yang berpengaruh signifikan terhadap strategi bagaimana sistem akuntansi manajemen harus diterapkan di lingkungan bisnis.

Akuntansi adalah bahasa bisnis yang berkomunikasi dengan pihak-pihak yang berkepentingan terkait dengan hasil operasi dan kondisi keuangan entitas melalui data akuntansi yang dipersiapkanuntuk pihak-pihak yang berkepentingan, seperti: pemegang saham, calon investor, karyawan, manajer, kreditur, dan pemerintah (Horngren, 2014). Sebagai contoh, manajer memerlukan informasi yang akan membantu mereka dalam kegiatan pengambilan keputusan dan pengendalian bisnis, misalnya diperlukan informasi mengenai taksiran harga jual, biaya, permintaan, posisi kompetitif dan profitabilitas berbagai produk dan layanan yang disediakan oleh perusahaan. Pemegang saham memerlukan 
informasi mengenai nilai investasi mereka dan pendapatan yang diperoleh dari kepemilikan saham mereka. Karyawan memerlukan informasi tentang kemampuan perusahaan untuk memenuhi tuntutan upah dan hak-hak karyawan lainnya. Kreditor dan penyalur modal pinjaman memerlukan informasi mengenai kemampuan perusahaan untuk memenuhi kewajiban finansialnya.

Saat ini kewirausahaan dan pengembangan usaha kecil, khususnya di Kabupaten Banyumas sebenarnya sudah mendapatkan dukungan yang cukup memadai dari pemerintah daerah dan pihak-pihak yang berkepentingan lainnya (Suyono, 2017). Dinas Tenaga Kerja Koperasi dan UKM Kabupaten Banyumas juga sudah banyak mengeluarkan beberapa regulasi untuk mendukung perkembangan jenis usaha ini termasuk regulasi keuangan seperti diberikannya dana bergulir untuk membantu keuangan UKM (Suyono dkk., 2016). Dengan demikian, UKM harus bisa mengoptimalkan dukungan dari pemerintah tersebut untuk bisa mengoptimalkan potensi yang mereka miliki sehingga pada akhirnya keberadaan UKM bisa turut mendukung program-program pemerintah seperti dalam hal penyediaan lapangan pekerjaan, pengurangan pengangguran, dan pengentasan kemiskinan.

Beberapa penelitian terkait dengan penerapapan akuntansi pada UKM sudah dilakukan oleh beberapa peneliti terdahulu di Indonesia seperti dalam Kurniawati dkk. (2012), Agustika dkk. (2015), Saragih dan Surikayanti (2015), dan Ernawati dkk. (2016). Kurniawati dkk. (2012) meneliti peran akuntansi bagi UMKM dengan mengambil 51 UMKM sebagai sampel di Salatiga dan menemukan bahwa sebagian besar UMKM di Salatiga sudah melakukan pencatatan atas penjualan, pembelian, persediaan, biaya gaji dan biaya lainnya, serta membuat pelaporan seperti: laporan penjualan, pembelian, persediaan dan penggajian. Agustika $d k k$. (2015) menggunakan metode kualitatif mengobservasi bagaimana 5 UKM di Sampang, Madura melakukan penyusunan laporan keuangan dalam rangka mendapatkan bantuan dana bergulir dari pemerintah. Hasilnya menemukan bahwa umumnya pelaku UKM sudah memiliki kesadaran akan pentingnya laporan keuanhgan sebuah usaha, namun mereka membuat pelaporan lengkap jika itu dibutuhkan atau bersifat insidental seperti untuk mendapatkan bantuan keuangan dari program pemerintah. Saragih dan Surikayanti (2015) mengevaluasi kesesuaian pelaporan keuangan UKM di Kecamatan Medan Perjuangan, Sumatera Utara dan menemukan bahwa UKM hanya melakukan pencatatan keuangan sederhana dan belum sesuai dengan SAK ETAP. Selanjutnya, Ernawati dkk. (2016) mengevaluasi penerapan akunansi pada UKM di Banjarmasin dan menemukan bahwa penerapan sistem akuntansi pada UKM di Banjarmasin masih sangat rendah.

Berbeda dengan penelitian sebelumnya di Indonesia yang umumnya mengevaluasi praktik akuntansi keuangan yang bersifat eksternal, penelitian ini mencoba mengevaluasi kesaradaran pelaku UKM di Banyumas akan pentingnya 
akuntansi manajemen khususnya dalam hal sistem pengendalian manajemenuntuk kepentingan pengembangan internal.Penelitian ini dikembangkan dari berbagai penelitian terdahulu dalam topic yang sama di luar negeri (Byrne dan Pierce, 2007; Wiedemann, 2015; Regondola, 2017) dengan melakukan penyesuaian beberapa instrumen untuk kasus di Indonesia. Sehingga tujuan dari penelitian ini adalah untuk:

1. Mengevaluasi tingkat kesadaran pemilik/pengelola UKM tentang pentingnya variabel-variabel sistem pengendalian manajemen yang mencakup perencanaan strategis, pengambilan keputusan, dan evaluasi dan pengendaliandalam mendukung pengelolaan UKM di Kabupaten Banyumas.

2. Mengevaluasihambatan-hambatan yang dihadapi oleh para pemilik/pengelola UKM dalam penerapan variabel-variabel sistem pengendalian manajemen yang mencakup perencanaan strategis, pengambilan keputusan, dan evaluasi dan pengendalianuntuk pengelolaan usaha mereka.

\section{TINJAUAN PUSTAKA DAN PENGEMBANGAN HIPOTESIS}

Penelitian ini menggunakan contingency theory yang menjelaskan bahwa tidak ada sistem dan manajemen yang bisa sesuai untuk semua organisasi, akan tetapi sangat bergantung pada kondisi situasional masing-masing perusahaan (Otley, 1980). Tulisan ini mencoba menggunakan konsep-konsep yang dikembangkan dalam contingency theory untuk mengevaluasi bagaimana kesadaran para pelaku UKM dalam menerapkan variabel - variabel sistem pengendalian manajemen yang mencakup perencanaan strategis, pengambilan keputusan, dan evaluasi dan pengendalian dalam mendukung pengelolaan usaha.

Sistem pengendalian manajemen merupakan bagian dari akuntansi manajemen dimana akuntansi manajemen berhubungan dengan penyediaan informasi keuangan dan non keuangan bagi para manajer untuk memastikan efisien dan efektivitas kinerja sebuah organisasi (Horngren, 2014). Selanjutnya akuntansi manajemen akan mengidentifikasi, mengukur, menganalisis dan mengumpulkan informasi akuntansi untuk para manajer yang akan digunakan untuk merencanakan, mengevaluasi dan mengendalikan sumber daya perusahaan untuk mencapai tujuan perusahaan (Horngren, 2014). Sehingga bisa dikatakan bahwa akuntansi manajemen merupakan sistem pendukung keputusan yang melayani manajemen di semua tingkatan dan dapat dianggap sebagai proses perbaikan berkelanjutan yang menambah nilai bagi perusahaan.

Secara umum, dapat dikatakan bahwa akuntansi manajemen memungkinkan organisasi menerima informasi tepat tentang perubahan di masing - masing departemen dan efeknya pada departemen lain dan organisasi secara keseluruhan. Akuntansi manajemen akan mendeteksi masalah pada tahap awal, memungkinkan manajemen untuk membuat keputusan bisnis yang lebih baik, meningkatkan keseluruhan kinerja serta kemajuan proses perencanaan dan 
pengendalian dan membantu memecahkan masalah (Byrne dan Pierce, 2007; Wiedemann, 2015). Oleh karena itu akuntansi manajemen memberikan informasi bernilai tinggi tentang perusahaan untuk memudahkan pengambilan keputusan bagi para manajer.

Sistem pengendalian manajemen umumnya dipahami sebagai proses yang berhubungan terutama dengan perencanaan, membantu dalam pengambilan keputusan, pengendalian dan penyediaan umpan balik ke unit perencanaan (Anthony dan Govindarajan, 2007). Organisasi yang sudah menerapkan konsep konsep sistem pengendalian manajemen biasanya mendapatkan manfaat dari instrumen yang berbeda untuk mencapai tujuan mereka. Instrumen tersebut dapat dibagi menjadi dua kategori, yaitu instrumen berorientasi tujuan dan instrumen berorientasi waktu (Byrne dan Pierce, 2007; Wiedemann, 2015). Instrumen berorientasi tujuan disebut juga instrumen strategis yang mencakup pasar dan posisi kompetitif perusahaan serta mengupayakan kemungkinan-kemungkinan perbaikan. Sedangkan instrumen berorientasi waktu disebut juga instrumen operasional yang akan berupaya menetapkan target operasi seperti likuiditas, profitabilitas dan efisiensi. Sehingga instrumen strategis berorientasi jangka panjang sedangkan instrumen operatif didasarkan pada kerangka waktu yang lebih pendek, yaitu kurang dari satu tahun (Byrne dan Pierce 2007).

Instrumen strategis meliputi perencanaan strategis, perumusan visi dan strategi,

analisis nilai pemegang saham, analisis SWOT, balanced scorecard, analisis siklus hidup produk, analisis pesaing, analisis gap, pengendalian investasi, analisis portofolio, analisis skenario, benchmarking, dan sebagainya. Instrumen operatif misalnya perencanaan operasi, penganggaran, analisis kunci indikator kinerja, analisis rasio, pelaporan, laporan arus kas, perhitungan margin kontribusi, analisis biaya-volume-laba, analisis break event point, analisis biaya-manfaat, activity based costing, analisis biaya overhead, analisis varians, dan sebagainya (Byrne dan Pierce, 2007; Wiedemann, 2015).

Dengan menggunakan konsep contingency theory maka dapat dikatakan bahwa tidak ada sistem akuntansi manajemen yang berlaku universal, akan tetapi kesuksesannya sangat bergantung pada keadaan masing-masing perusahaan, dalam hal ini keadaan masing-masing UKM di Kabupaten Banyumas. Otley (1980) berpendapat bahwa contingency theory sering digunakan dalam konteks aspek organisasi dan perilaku, namun pada dasarnya awal mula teori ini digunakan untuk menjelaskan bagaimana faktor-faktor tertentu mempengaruhi organisasi secara keseluruhan. Dengan menggunakan contingency theory penelitian ini akan mengevaluasi sejauh mana kesadaran para pengelola UKM menerapkan variable - variabel sistem pengendalian manajemen yang mencakup perencanaan strategis, pengambilan keputusan, dan evaluasi dan pengendalian 
untuk pengelolaan usaha mereka, serta kendala-kendala apa saja yang mereka hadapi dalam menerapkan sistem pengendalian manajemen pada usaha mereka.

\section{METODE PENELITIAN}

\section{Rancangan Penelitian}

Penelitian ini merupakan mini riset yang menggunakan pendekatan gabungan kuantitatif dan kualitatif. Pendekatan kuantitatif digunakan untuk mengukur tingkat kesadaran para pengelola UKM terhadap pentingnya penerapan sistem pengendalian manajemen dalam pengelolaan usaha mereka. Adapun pendekatan kualitatif dilakukan untuk mengobservasi kendala-kendala yang dihadapi para pengelola UKM dalam penerapan sistem pengendalian manajemen tersebut.

\section{Responden Penelitian dan Teknik Penarikan Sampel}

Responden adalah pemilik dan pengelola UKM di Kabupaten Banyumas. Pengambilan sampel penelitian dilakukan menggunakan pendekatan purposive sampling dengan menerapkan kriteria tertentu yaitu ukuran UKM yang sudah layak menerapkan sistem pengendalian manajemen dalam pengelolaan usahanya. Pertimbangan kelayakan besarnya ukuran UKM yang bisa diikutkan sebagai responden ditentukan berdasarkan pertimbangan peneliti. Pendekatan purposive ini mungkin memiliki keterbatasan karena sangat bergantung dengan pertimbangan subyektif peneliti, namun pendekatan ini sangat berguna terutama bila populasinya sangat besar (Etikan dkk., 2016).

Sebanyak 55 kuesioner dibagikan kepada 55 pemilik UKM yang dipandang berdasarkan pertimbangan peneliti memenuhi kriteria untuk menerapkan elemen - elemen akuntansi manajemen dalam perusahaan. Penyebaran kuesioner dan wawancara dengan responden dilakukan selama bulan Oktober dan November 2017 pada pemilik atau pengelola UKM di Kabupaten Banyumas. Sedangkan kategori usaha mikro tidak dimasukan dalam penelitian ini karena menurut pertimbangan peneliti belum cukup layak untuk menerapkan sistem pengendalian manajemen. Responden penelitian adalah UKM di Kabupaten Banyumas yang bergerak dalam usaha perdagangan (toko tradisional) sebanyak 20, rumah makan sebanyak 18 , industri pengolahan produk makanan sebanyak 12, dan industri batik sebanyak 5 .

\section{Pengukuran Variabel dan Instrumen Penelitian}

Variabel utama dalam penelitian ini adalah tiga komponen utama sistem pengendalian manajemen yang meliputi perencanaan strategis, pengambilan keputusan, dan evaluasi dan pengendalian. Selanjutnya, instrumen yang digunakan dalam penelitian ini adalah kuesioner yang dirancang oleh peneliti dengan bersumber dari beberapa terdahulu (Byrne dan Pierce, 2007; Wiedemann, 
2015; Regondola, 2017). Perbedaan penelitian ini dengan penelitian terdahulu adalah dalam penelitian terdahulu hanya menggunakan pendekatan diskriptif kuantitatif dengan penyebaran kuesioner, sedangkan dalam penelitian ini disamping data dikumpulkan melalui kuesioner juga melalui wawancara dengan responden. Kuesioner digunakan untuk mengukur tingkat kepedulian responden akan pentingnya sistem pengendalian majalemen dalam pengelolaan UKM sedangkan wawancara digunakan untuk mengetahui kendala apa saja yang dihadapi responden dalam menerapkan variabel - variabel sistem pengendalian manajemen. Secara garis besar variabel - variabel sistem pengendalian manajemen dan indikator - indikatornya ditampilkan dalam Tabel 1.

Tabel 1. Pengukuran Variabel Penelitian

\begin{tabular}{clc}
\hline Variabel & \multicolumn{1}{c}{ Indikator } & Skala \\
\hline Perencanaan Strategis & • Pengawasan kegiatan usaha sehari-hari. & Ordinal \\
(Hopper $d k k .$, 1999; & - Kemampuan memotivasi dan mengarahkan & \\
Byrne dan Pierce, & karyawan. & \\
2007; Wiedemann, & - Pendelegasian tugas kepada karyawan. & \\
2015; Regondola, & - Manajemen konflik dan pemecahan masalah. & \\
2017). & - Perencanaan jangka panjang, jangka & \\
& menengah, dan jangka pendek. & Ordinal \\
Pengambilan & - Mengandalkan intuisi bisnis. & \\
keputusan & - Melibatkan seluruh karyawan. & \\
(Hopper dkk., 1999; & - Mempertimbangkan data historis, asumsi, dan & \\
Byrne dan Pierce, & tren secara akurat. & \\
2007; Wiedemann, & - Mempertimbangkan hasil jangka pendek dan & \\
2015; Regondola, & jangka panjang. & Ordinal \\
2017). & & \\
\hline Evaluasi dan & - Membandingkan kinerja dengan standar. & \\
Pengendalian & - Mencari penyebab penyimpangan dari standar. & \\
(Wiedemann, 2015; & $\bullet$ Menggunakan ukuran-ukuran kuantitatif dan & \\
Regondola, 2017; & kualitatif. & \\
Horngren, 2018). & - Menjadikan umpan balik untuk tindakan & \\
& korektif. & \\
\hline
\end{tabular}

Tabel 2. Interpretasi Skala Likert

\begin{tabular}{ccc}
\hline Rentang Rata - Rata & Interpretasi & Makna Tingkat Kepedulian \\
\hline $4.20-5.00$ & Sangat peduli & Sangat Tinggi \\
$3.40-4.19$ & Peduli & Tinggi \\
$2.60-3.39$ & Netral & Netral \\
$1.80-2.59$ & Tidak Peduli & Rendah \\
$1.00-1.79$ & Sangat Tidak Peduli & Sangat Rendah \\
\hline
\end{tabular}

Kuesioner diukur dengan skala Likert $(5=$ sangat peduli, $4=$ peduli, $3=$ netral, 2 = tidak peduli, 1 = sangat tidak peduli). Selanjutnya data dari jawaban responden dirata - rata untuk skor masing - masing item kuesioner keseluruhan 
responden dan diklasifikasikan jawabannya untuk menentukan tingkat kepedulian dengan kriteria yang diadopsi dari pendapat Sullivan and Artino-Jr (2013) dalam menginterpretasikan skor dalam skala Likert seperti dalam Tabel 2.

\section{Analisis Data}

Karena pendekatan kuantitatif dalam penelitian menggunakan kuesioner sebagai instrumen, maka perlu dilakukan uji validitas dan reliabilitas atas instrumen tersebut sebelum diberikan kepada responden sesungguhnya. Beberapa rekan dosen dan mahasiswa diminta mengisi kuesioner dan dilakukan uji validitas dan reliabilitas, setelah itu data disebar ke 55 pengelola UKM yang menjadi sampel.

Uji validitas merupakan uji keakuratan data yang digunakan dalam penelitian. Pengukuran validitas menggunakan teknik corrected item-total correlation, yaitu dengan cara mengkorelasi skor tiap item dengan skor totalnya. Uji validitas menggunakan statistik Korelasi Product Moment (Anderson dkk., 2016).

$$
r=\frac{n\left(\sum x y\right)-\left(\sum x \sum y\right)}{\sqrt{\left[\left(n \sum x^{2}\right)-\left(\sum x\right)^{2}\right]\left[n \sum y^{2}-\left(\sum y\right)^{2}\right]}}
$$

Keterangan :

$\mathrm{r}=$ koefisien korelasi item dengan total pertanyaan

$\mathrm{n}=$ jumlah responden

$\mathrm{x}=$ skor pertanyaan

$\mathrm{y}=$ skor total populasi

Dengan tingkat signifikansi $5 \%$ sehingga kriteria pengujian validitas butir kuesioner adalah :

Jika $r_{\text {hitung }}>r_{\text {tabel }}$ maka butir kuesioner tersebut valid

Jika $\mathrm{r}_{\text {hitung }} \leq \mathrm{r}_{\text {tabel }}$ maka butir kuesioner tersebut tidak valid

Sedangkan uji reliabilitas digunakan untuk menguji konsistensi data yang dikumpulkan. Dalam penelitian ini reliabilitas diukur melalui pendekatan Realibilitas Konsistensi Internal, yaitu konsep yang menitikberatkan pada konsistensi di antara butir-butir pertanyaan atau pernyataan dalam suatu instrumen. Teknik pengujian yang digunakan adalah Cronbach's alpha dengan rumus sebagai berikut (Anderson $d k k$., 2016):

$$
r=\left(\frac{k}{k-1}\right)\left(1-\frac{\sum{\sigma_{b}}^{2}}{\sigma^{2}}\right)
$$

Keterangan:

$$
\begin{array}{ll}
\mathrm{r} & =\text { Reliabilitas instrumen (pertanyaan) } \\
\mathrm{k} & =\text { Jumlah butir pertanyaan } \\
\sigma^{2} & =\text { Varian total }
\end{array}
$$


$\sum{\sigma_{b}}^{2}=$ Jumlah varian butir

Dimana $\sigma^{2}$ diperoleh dengan rumus:

$$
\sigma^{2}=\frac{\sum x^{2} \frac{\left(\sum x^{2}\right)}{n}}{n}
$$

Keterangan:

$\sigma^{2}=$ varian total

$\mathrm{n}=$ jumlah responden

$\mathrm{x} \quad=$ nilai skor yang dipilih (total nilai dari nomor-nomor butir pertanyaan)

Dengan degree of freedom $(\mathrm{df})=(\mathrm{n}-2)$ dan $\alpha=0,05$ sehingga kriteria pengujian reliabilitas kuesioner adalah :

Jika $r_{\text {alpha }}>r$ tabel maka butir kuesioner tersebut reliabel

Jika $r_{\text {alpha }} \leq r_{\text {tabel }}$ maka butir kuesioner tersebut tidak reliabel

\section{HASIL PENGUJIAN HIPOTESIS DAN PEMBAHASAN}

Distribusi Responden Berdasarkan Usia, Jenis Kelamin, Tingkat Pendidikan dan Umur Usaha.

Penelitian ini mendapatkan 55 sampel pemilik/pengelola UKM di Kabupaten Banyumas, dengan rincian sebanyak 20 UKM toko, 18 UKM rumah makan, 12 UKM pengolahan produk makanan, dan 5 UKM batik. Tabel 3 menunjukkan distribusi responden berdasarkan usia, jenis kelamain, tingkat pendidikan pemilik/pengelola, dan umur usaha untuk masing-masing jenis UKM.

Tabel 3. Distribusi Responden Berdasarkan Usia, Jenis Kelamin, Tingkat Pendidikan, dan Umur Usaha

\begin{tabular}{|c|c|c|c|c|c|c|c|c|c|c|}
\hline & \multicolumn{2}{|c|}{ UKM Toko } & \multicolumn{2}{|c|}{$\begin{array}{c}\text { UKM Rumah } \\
\text { Makan }\end{array}$} & \multicolumn{2}{|c|}{$\begin{array}{c}\text { UKM } \\
\text { Pengolahan } \\
\text { Makanan } \\
\end{array}$} & \multicolumn{2}{|c|}{ UKM Batik } & \multicolumn{2}{|c|}{ TOTAL } \\
\hline & $\mathrm{F}$ & $\%$ & $\mathrm{~F}$ & $\%$ & $\mathrm{~F}$ & $\%$ & $\mathrm{~F}$ & $\%$ & $\mathrm{~F}$ & $\%$ \\
\hline \multicolumn{11}{|l|}{ Usia Pemilik } \\
\hline 20-29 tahun & 4 & 20 & 0 & 0 & 0 & 0 & 0 & 0 & 4 & 7 \\
\hline 30-39 tahun & 5 & 25 & 4 & 22 & 1 & 8 & 0 & 0 & 10 & 18 \\
\hline 40-49 tahun & 6 & 30 & 7 & 39 & 5 & 42 & 1 & 20 & 19 & 35 \\
\hline 50- 59 tahun & 4 & 20 & 5 & 28 & 4 & 33 & 2 & 40 & 15 & 27 \\
\hline 60 tahun lebih & 1 & 5 & 2 & 11 & 2 & 17 & 2 & 40 & 7 & 13 \\
\hline TOTAL & 20 & 100 & 18 & 100 & 12 & 100 & 5 & 100 & 55 & 100 \\
\hline \multicolumn{11}{|l|}{ Jenis Kelamin } \\
\hline Laki-laki & 13 & 65 & 10 & 56 & 8 & 67 & 4 & 80 & 35 & 67 \\
\hline Perempuan & 7 & 35 & 8 & 44 & 4 & 33 & 1 & 20 & 20 & 33 \\
\hline TOTAL & 20 & 100 & 18 & 100 & 12 & 100 & 5 & 100 & 55 & 100 \\
\hline \multicolumn{11}{|l|}{ Pendidikan } \\
\hline Sarjana & 5 & 25 & 9 & 50 & 3 & 25 & 4 & 80 & 21 & 38 \\
\hline D3 & 4 & 20 & 7 & 39 & 4 & 33 & 0 & 0 & 15 & 27 \\
\hline SMA ke bawah & 11 & 55 & 2 & 11 & 5 & 42 & 1 & 20 & 19 & 35 \\
\hline
\end{tabular}




\begin{tabular}{|c|c|c|c|c|c|c|c|c|c|c|}
\hline TOTAL & 20 & 100 & 18 & 100 & 12 & 100 & 5 & 100 & 55 & 100 \\
\hline \multicolumn{11}{|l|}{ Umur Usaha } \\
\hline 1-5 Tahun & 0 & 0 & 9 & 50 & 0 & 0 & 0 & 0 & 9 & 16 \\
\hline 6-10 Tahun & 3 & 15 & 5 & 28 & 3 & 25 & 0 & 0 & 11 & 20 \\
\hline 11-15 Tahun & 9 & 45 & 4 & 22 & 4 & 33 & 2 & 40 & 19 & 35 \\
\hline 16 Tahun atau lebih & 8 & 40 & 0 & 0 & 5 & 42 & 3 & 60 & 16 & 29 \\
\hline TOTAL & 20 & 100 & 18 & 100 & 12 & 100 & 5 & 100 & 55 & 100 \\
\hline
\end{tabular}

Keterangan: $\mathbf{F}$ = frekuensi

Tabel 3 menyajikan data bahwa mayoritas usia pemilik UKM toko, UKM rumah makan dan UKM pengolahan makanan ada di kelompok usia 40-49 tahun yaitu dengan persentase secara berurutan adalah 30\%, 39\%, dan 42\%. Sedangkan mayoritas usia pemilik UKM batik antara 50-59 tahun dan di atas 60 tahun dengan prosentase masing-masing adalah 40\%. Adapun untuk jenis kelamin maka semua jenis UKM pemiliknya didominasi oleh laki-laki masing-masing dengan persentase 65\% untuk UKM toko, 56\% untuk UKM rumah makan, 67\% untuk UKM pengolahan makanan, dan $80 \%$ untuk UKM batik.

Sedangkan untuk tingkat pendidikan pemilik maka pemilik masing-masing jenis UKM mempunyai tingkat pendidikan yang berbeda-beda. Untuk UKM toko dan UKM pengolahan makanan maka mayoritas pemiliknya berpendidikan SMA ke bawah yaitu masing-masing adalah $55 \%$ dan $42 \%$. Sedangkan pemilik UKM rumah makan dan UKM batik mayoritas berpendidikan sarjana, yaitu masingmasing $50 \%$ dan $80 \%$.

Terkait dengan usia usaha, maka UKM toko mayoritasnya, yaitu $45 \%$ berusia antara 11-15 tahun, sedangkan UKM rumah makan maka mayoritas merupakan usaha baru yang berusia kurang dari 5 tahun (50\%). Adapun untuk UKM pengolahan makanan dan UKM batik maka mayoritas usahanya sudah lebih dari 16 tahun dengan prosentase secara berurutan $42 \%$ dan $60 \%$.

\section{Uji Validitas dan Reliabilitas Instrumen}

Untuk menguji validitas kuesioner digunakan rumus korelasi product moment seperti yang dijelaskna dalam bagian metodologi penelitian, selanjutnya hasil uji validitas untuk masing - masing variabel disajikan dalam Tabel 4 sampai Tabel 6.

Tabel 4. Hasil Uji Validitas Kuesioner Variabel Perencanaan Strategis

\begin{tabular}{cccc}
\hline Item & rhitung & $\begin{array}{c}\text { rtabel } \\
\text { (Taraf Kepercayaan 95\%) }\end{array}$ & Keterangan \\
\hline 1 & 0,433 & 0,362 & Valid \\
2 & 0,433 & 0,362 & Valid \\
3 & 0,397 & 0,362 & Valid \\
4 & 0,413 & 0,362 & Valid \\
5 & 0,382 & 0,362 & Valid \\
\hline
\end{tabular}


Berdasarkan Tabel 4 dapat diketahui bahwa nilai $\mathrm{r}_{\text {hitung }}$ korelasi product moment semua item pertanyaan dari variabel perencanaan strategis lebih besar dari nilai kritis ( $\mathrm{r}$ tabel) sebesar 0,362 pada tingkat kepercayaan 95\%. Dengan demikian, maka seluruh item pertanyaan variabel perencanaan strategis dinyatakan valid.

Tabel 5. Hasil Uji Validitas Kuesioner Variabel Pengambilan Keputusan

\begin{tabular}{llll}
\hline & Item & rhitung & \multicolumn{1}{c}{ rtabel } \\
(Taraf Kepercayaan 95 \%) & Keterangan \\
\hline 1 & 0,482 & 0,362 & Valid \\
2 & 0,427 & 0,362 & Valid \\
3 & 0,401 & 0,362 & Valid \\
4 & 0,450 & 0,362 & Valid \\
\hline
\end{tabular}

Berdasarkan Tabel 5 dapat diketahui bahwa nilai $\mathrm{r}$ hitung korelasi product moment semua item pertanyaan dari variabel pengambilan keputusan lebih besar dari nilai kritis ( $\mathrm{r}$ tabel) sebesar 0,362 pada tingkat kepercayaan 95\%. Dengan demikian, maka seluruh item pertanyaan variabel pengambilan keputusa dinyatakan valid.

Tabel 6. Hasil Uji Validitas Kuesioner Variabel Evaluasi dan Pengendalian

\begin{tabular}{lcll}
\hline Item & $\mathrm{r}_{\text {hitung }}$ & $\begin{array}{c}\mathrm{r}_{\text {tabel }} \\
\text { (Taraf Kepercayaan 95\%) }\end{array}$ & Keterangan \\
\hline 1 & 0,439 & 0,362 & Valid \\
2 & 0,401 & 0,362 & Valid \\
3 & 0,514 & 0,362 & Valid \\
4 & 0,698 & 0,362 & Valid \\
\hline
\end{tabular}

Dari hasil pengujian validitas dapat diketahui bahwa nilai $\mathrm{r}$ hitung korelasi product moment semua item pertanyaan dari variabel evaluasi dan pengendalian lebih besar dari nilai kritis ( $\mathrm{r}$ tabel) sebesar 0,362 pada tingkat kepercayaan $95 \%$. Dengan demikian, maka seluruh item pertanyaan variabel evaluasi dan pengendalian dinyatakan valid.

Untuk menguji reliabilitas kuesioner atau pertanyaan digunakan rumus Cronbach's alpha seperti yang dijelaskan dalam bagian metodologi penelitian. Suatu kuesioner penelitian dinyatakan reliabel apabila nilai $\mathrm{r}$ hitung ( $\mathrm{r}$ total) lebih besar dari nilai $r$ tabel. Hasil pengujian reliabilitas kuesioner dapat dilihat pada Tabel 6.

Tabel 7 menunjukkan bahwa nilai $r_{\text {total }}$ yang dihitung dengan rumus Cronbach's alphauntuk seluruh variabel lebih besar dari tabel sehingga dapat didimpulkan bahwa seluruh item kuesioner untuk tiap-tiap variabel adalah reliabel. 
Tabel 7. Pengujian Reliabilitas Kuesioner

\begin{tabular}{lccc}
\hline \multicolumn{1}{c}{ Variabel } & $\begin{array}{c}\text { Nilai } \\
\text { Reliabilitas } \\
(\mathbf{r} \text { total) }\end{array}$ & $\begin{array}{c}\text { rtabel } \\
\text { (Taraf Kepercayaan 95 \%) }\end{array}$ & Keterangan \\
\hline Perencanaan Strategis & 0,753 & 0,362 & Reliabel \\
Pengambilan Keputusan & 0,842 & 0,362 & Reliabel \\
Evaluasi dan Pengendalian & 0,705 & 0,362 & Reliabel \\
\hline
\end{tabular}

\section{Analisis Diskriptif Jawaban Responden}

\section{Jawaban Responden untuk Variabel Perencanaan Strategis}

Rata-rata jawaban responden untuk tiap jenis UKM terkait dengan itemitem pertanyaan untuk perencanaan strategis dapat dilihat pada Tabel 8. Tabel 8 tersebut menyajikan penilaian persepsi responden terhadap sistem pengendalian manajemen pada UKM di Kabupaten Banyumas dalam hal perencanaan strategis. Untuk indikator pengawasan kegiatan usaha sehari-hari maka rata-rata skor jawaban responden keseluruhan jenis UKM adalah 4,40 yang berarti sangat peduli dengan tingkat kepedulian yang sangat tinggi. Hal ini berarti bahwa seluruh responden meyakini sangat perlunya kegiatan usaha sehari-hari selalu dilakukan pengawasan untuk memastikan bahwa karyawan bisa menjalankan pekerjaannya sesuai dengan apa yang ditetapkan dalam kebijakan perusahaan.

Adapun untuk indikator kemampuan memotivasi dan mengarahkan karyawan maka rata-rata skor jawaban responden keseluruhan jenis UKM adalah 4,02 yang berarti peduli dengan tingkat kepedulian yang tinggi. Ini berarti responden yakin bahwa karyawan harus selalu diberikan motivasi kerja secara teratur supaya produktivitas kerja mereka bisa maksimal.

Selanjutnya untuk indikator pendelegasian tugas kepada karyawan maka rata - rata skor jawaban responden untuk semua jenis UKM adalah 3.97 yang berarti peduli dengan tingkat kepedulian yang tinggi. Kemudian untuk indikator manajemen konflik dan pemecahan masalah maka rata-rata skor jawaban responden adalah 4,34 yang berarti sangat peduli dengan tingkat kepedulian sangat tinggi. Terakhir, terkait dengan indikator perencanaan jangka panjang, jangka menengah, dan jangka pendek maka rata-rata skor jawaban responden untuk seluruh jenis UKM adalah 3,93 yang berarti peduli dengan tingkat kepedulian yang tinggi. Sehingga dapat disimpulkan bahwa tingkat kepedulian pemilik/pengelola UKM di Kabupaten Banyumas terhadap variabel perencanaan strategis adalah tinggi. 
Tabel 8. Skor Rata - Rata Jawaban Responden untuk Variabel Perencanaan Strategis

\begin{tabular}{|c|c|c|c|c|c|c|}
\hline $\begin{array}{l}\text { Indikator Perencanaan } \\
\text { Strategis }\end{array}$ & $\begin{array}{l}\text { UKM } \\
\text { Toko } \\
\text { N=20 }\end{array}$ & $\begin{array}{c}\text { UKM } \\
\text { Rumah } \\
\text { Makan } \\
\mathrm{N}=18\end{array}$ & $\begin{array}{c}\text { UKM } \\
\text { Pengolahan } \\
\text { Makanan } \\
\mathbf{N}=12\end{array}$ & $\begin{array}{l}\text { UKM } \\
\text { Batik } \\
\text { N = 5 }\end{array}$ & $\begin{array}{c}\text { Skor Rata- } \\
\text { rata Seluruh } \\
\text { UKM } \\
\mathbf{N}=\mathbf{5 5}\end{array}$ & Kesimpulan \\
\hline $\begin{array}{l}\text { 1. Pengawasan kegiatan } \\
\text { usaha sehari-hari. }\end{array}$ & 4,32 & 4,43 & 4,16 & 4,70 & 4,40 & $\begin{array}{l}\text { Sangat } \\
\text { Peduli }\end{array}$ \\
\hline $\begin{array}{ll}2 . & \text { Kemampuan } \\
& \text { memotivasi dan } \\
& \text { mengarahkan } \\
& \text { karyawan. }\end{array}$ & 3,66 & 4,25 & 3,55 & 4.60 & 4,02 & Peduli \\
\hline $\begin{array}{ll}\text { 3. } & \text { Pendelegasian tugas } \\
\text { kepada karyawan. }\end{array}$ & 3,51 & 3,75 & 4,05 & 4,55 & 3,97 & Peduli \\
\hline $\begin{array}{l}\text { 4. Manajemen konflik } \\
\text { dan pemecahan } \\
\text { masalah. }\end{array}$ & 4,35 & 4,15 & 4,20 & 4,65 & 4,34 & $\begin{array}{l}\text { Sangat } \\
\text { Peduli }\end{array}$ \\
\hline $\begin{array}{ll}\text { 5. } & \text { Perencanaan jangka } \\
\text { panjang, jangka } \\
\text { menengah, dan } \\
\text { jangka pendek. }\end{array}$ & 3,45 & 3,55 & 4,00 & 4,70 & 3,93 & Peduli \\
\hline Rata - Rata & $\mathbf{3 , 8 9}$ & 4,03 & 3,99 & 4.64 & 4.13 & Peduli \\
\hline
\end{tabular}

Data dari hasil analisis diskriptif di atas dapat disimpulkan bahwa bahwa pemilik/pengelola UKM di Banyumas mempunyai kepedulian yang tinggi terkait dengan variabel perencanaan strategis. Akan tetapi data kualitatif yang diperoleh melalui wawancara dengan para responden menunjukkan bahwa mereka mempunyai banyak kendala dalam mempraktekan indikator - indikator perencanaan strategis dalam usaha mereka. Kendala yang paling utama adalah karena UKM beroperasi dengan sumber daya yang terbatas sehingga hal ini menyebabkan UKM tidak mampu secara maksimal menjalankan indikator indikator perencanaan strategis di atas. Kendala yang lain adalah karena beberapa pemilik UKM, khususnya UKM Toko dan UKM pengolahan makanan berpendidikan rendah sehingga mereka tidak memiliki pengetahuan yang memadahi seperti dalam hal memotivasi karyawan, pendelegasian tugas dan wewenang, manajemen konflik dan menyusun perencanaan yang baik.

\section{Jawaban Responden untuk Variabel Pengambilan Keputusan}

Rata - rata jawaban responden untuk item-item pertanyaan dalam variabel pengambilan keputusan dapat dilihat pada Tabel 9. Disajikan pada Tabel 9 mengenai penilaian persepsi responden terhadap sistem pengendalian manajemen pada UKM di Kabupaten Banyumas dalam hal pengambilan keputusan. Untuk indikator pengawasan mengandalkan intuisi bisnismaka rata - rata skor jawaban 
responden keseluruhan jenis UKM adalah 4,04 yang berarti peduli. Hal ini berarti bahwa responden mempunyai tingkat kepedulian yang tinggiakan pentingnya intusi bisnis dalam proses pengambilan keputusan, sehingga akan didapatkan hasil keputusan yang sangat mendukung usaha mereka.

Tabel 9. Skor Rata - Rata Jawaban Responden untuk Variabel Pengambilan Keputusan

\begin{tabular}{|c|c|c|c|c|c|c|}
\hline $\begin{array}{l}\text { Indikator Pengambilan } \\
\text { Keputusan }\end{array}$ & $\begin{array}{l}\text { UKM } \\
\text { Toko } \\
\text { N=20 }\end{array}$ & $\begin{array}{c}\text { UKM } \\
\text { Rumah } \\
\text { Makan } \\
\text { N=18 }\end{array}$ & $\begin{array}{c}\text { UKM } \\
\text { Pengolahan } \\
\text { Makanan } \\
\mathbf{N}=12\end{array}$ & $\begin{array}{l}\text { UKM } \\
\text { Batik } \\
\mathbf{N}=5\end{array}$ & $\begin{array}{c}\text { Skor Rata- } \\
\text { Rata } \\
\text { Seluruh } \\
\text { UKM } \\
\text { N = 55 }\end{array}$ & Kesimpulan \\
\hline $\begin{array}{l}\text { 1. Mengandalkan intuisi } \\
\text { bisnis }\end{array}$ & 4,37 & 3,65 & 4,27 & 3,85 & 4,04 & Peduli \\
\hline $\begin{array}{l}\text { 2. Melibatkan seluruh } \\
\text { karyawan }\end{array}$ & 4,25 & 3,75 & 4,55 & 4.60 & 4,29 & $\begin{array}{l}\text { Sangat } \\
\text { Peduli }\end{array}$ \\
\hline $\begin{array}{ll}\text { 3. } & \text { Mempertimbangkan data } \\
\text { historis, asumsi, dan tren } \\
\text { secara akurat }\end{array}$ & 3,85 & 4,25 & 4,00 & 4,50 & 4,15 & Peduli \\
\hline $\begin{array}{ll}\text { 4. } & \text { Mempertimbangkan } \\
\text { hasil jangka pendek dan } \\
\text { jangka panjang }\end{array}$ & 4,20 & 4,35 & 4,15 & 3,75 & 4,11 & Peduli \\
\hline Rata-Rata & 4,17 & 4,00 & 4,24 & 4.18 & 4.15 & Peduli \\
\hline
\end{tabular}

Adapun untuk indikator melibatkan seluruh karyawan dalam proses pengambilan keputusan maka rata - rata skor jawaban responden keseluruhan jenis UKM adalah 4,29 yang berarti sangat peduli. Hal ini berarti responden mempunyai tingkat kepedulian yang sangat tinggiakan pentingnya bermusyawarah dan melibatkan seluruh karyawan dalam proses pengambilan keputusan. Dengan demikian semua karyawan akan turut bertanggung jawab mensukseskan keputusan yang sudah diambil karena mereka terlibat dalam proses pengambilan keputusan tersebut.

Selanjutnya untuk indikator mempertimbangkan data historis, asumsi, dan tren secara akurat dalam proses pengambilan keputusan maka rata - rata skor jawaban responden untuk semua jenis UKM adalah 4,15 yang berarti peduli. Hal ini berarti seluruh responden mempunyai tingkat kepedulian yang tinggiakan pentingnya melihat data masa lalu perusahaan, asumsi-asumsi yang di bangun ke depan, dan mempertimbangkan pergerakan tren bisnis mereka dalam beberapa tahun terakhir.

Kemudian untuk indikator mempertimbangkan hasil jangka pendek dan jangka panjang maka rata-rata skor jawaban responden adalah 4,11 yang berarti peduli. Ini berarti bahwa responden mempunyai tingkat kepedulian tinggiakan 
pentingnya memperhatikan hasil yang akan dicapai dari keputusan yang akan diambil baik untuk jangka pendek maupun jangka panjang. Dengan kemampuan perusahaan menganalisis hasil dalam jangka pendek maupun jangka panjang maka UKM bisa memprediksi eksistensi mereka dalam jangka pendek maupun jangka panjang ditengah persaingan usaha yang semakin dinamis dan kompetitif.

Secara keseluruhan, data pada Tabel 9 menyimpulkan bahwa pemilik/pengelola UKM di Banyumas mempunyai kepedulian yang tinggi terkait dengan variabel pengambilan keputusan. Sedangkan data hasil wawancara dengan para responden juga berhasil mengungkapkan beberapa kendala yang di hadapi UKM di Kabupaten Banyumas dalam mengimplementasikan item-item manajemen strategis terkait pengambilan keputusan seperti dalam Tabel 9. Diantara informasi yang dapat diungkap oleh peneliti melalui wawancara dengan responden adalah bahwa kurangnya pengetahuan yang dimiliki mayoritas responden khususnya yang berpendidikan rendah akan perlunya melibatkan seluruh karyawan dalam pengambilan keputusan, perlunyamempertimbangkan data historis, asumsi, dan tren bisnis secara akurat, serta perlunya mempertimbangkan capaian hasil jangka pendek maupun jangka panjang dalam proses pengambilan keputusan. Disamping itu juga terungkap dalam wawancara bahwa karena tingkat persaingan usaha yang sangat tinggi fokus responden selama ini lebih tertuju pada bagaimana mempertahankan pangsa pasar dan kalau mungkin meningkatkannya sehingga tidak terlalu memikirkan poin - poin dalam pengambilan keputusan tersebut walaupun ketika diajukan kueioner sebenarnya responden mempunyai tingkat kepedulian yang tinggi akan item-item pengambilan keputusan tersebut

\section{Jawaban Responden untuk Variabel Evaluasi Pengendalian}

Rata-rata jawaban responden untuk item-item pertanyaan dalam variabel evaluasi dan pengendalian dapat dilihat pada Tabel 10. Dipat dilihat pada Tabel 10 bahwa penilaian persepsi responden terhadap sistem pengendalian manajemen pada UKM di Kabupaten Banyumas dalam halevaluasi dan pengendalian. Untuk indikator membandingkan kinerja dengan standar maka rata-rata skor jawaban responden keseluruhan jenis UKM adalah 4,13 yang berarti peduli. Hal ini berarti bahwa responden mempunyai tingkat kepedulian yang tinggi akan perlunya membandingkan kinerja dengan standar yang sudah ditetapkan oleh perusahaan dalam evaluasi dan pengendalian. Hal ini dipandang penting karena dengan membandingkan standar dengan capaian dapat digunakan sebagai alat evaluasi kinerja manajerial perusahaan. Namun demikian, walaupun data kuesioner menunjukkan tingkat kepedulian yang tinggi dari para responden akan pentingnya membandingkan kinerja dengan standar, data yang diperoleh dari hasil wawancara menunjukkan bahwa umumnya responden belum membuat ukuran-ukuranstandar seperti biaya standar, target capaian, dan sebagainya. Hal ini karena mereka 
umumnya terkendala dengan kemampuan merumuskan standar khususnya bagi UKM yang pemiliknya berpendidikan rendah. Data yang diperoleh dari wawancara juga menunjukkan bahwa mayoritas responden belum membuat dokumentasi yang terstruktur akan upaya membandingkan kinerja antar tahun. Selama ini mereka hanya melakukan evaluasi secara tidak tertulis dan tidak terdokumentasi dengan memastikan bahwa usaha mereka masih mampu mempertahankan pangsa pasar, mampu mendapatkan keuntungan, dan pada akhirnya tetap mampu bertahan ditengah persaingan usaha yang semakin dinamis.

Tabel 10. Skor Rata-rata Jawaban Responden untuk Variabel Evaluasi dan Pengendalian

\begin{tabular}{|c|c|c|c|c|c|c|}
\hline $\begin{array}{c}\text { Indikator Pengambilan } \\
\text { Keputusan }\end{array}$ & $\begin{array}{l}\text { UKM } \\
\text { Toko } \\
\text { N=20 }\end{array}$ & $\begin{array}{c}\text { UKM } \\
\text { Rumah } \\
\text { Makan } \\
\text { N=18 }\end{array}$ & $\begin{array}{c}\text { UKM } \\
\text { Pengolahan } \\
\text { Makanan } \\
\mathbf{N}=12\end{array}$ & $\begin{array}{l}\text { UKM } \\
\text { Batik } \\
\mathbf{N}=5\end{array}$ & $\begin{array}{c}\text { Skor Rata-rata } \\
\text { Seluruh UKM } \\
\quad \mathbf{N}=\mathbf{5 5}\end{array}$ & Kesimpulan \\
\hline $\begin{array}{l}\text { 1. Membandingkan } \\
\text { kinerja dengan } \\
\text { standar }\end{array}$ & 4,05 & 3,75 & 4,00 & 4,70 & 4,13 & Peduli \\
\hline $\begin{array}{ll}\text { 2. } & \text { Mencari penyebab } \\
\text { penyimpangan dari } \\
\text { standar }\end{array}$ & 3,55 & 3,50 & 3,75 & 4.50 & 3,83 & Peduli \\
\hline $\begin{array}{ll}\text { 3. } & \text { Menggunakan } \\
\text { ukuran-ukuran } \\
\text { kuantitatif dan } \\
\text { kualitatif } \\
\end{array}$ & 3,75 & 3,95 & 4,00 & 4,55 & 4,06 & Peduli \\
\hline $\begin{array}{l}\text { 4. Menjadikan umpan } \\
\text { balik untuk tindakan } \\
\text { korektif }\end{array}$ & 3,85 & 4,00 & 3,75 & 4,15 & 3.94 & Peduli \\
\hline Rata-rata & 3,80 & 3,80 & 3,89 & 4.50 & 3.99 & Peduli \\
\hline
\end{tabular}

Adapun untuk indikator mencari penyebab penyimpangan dari standardalam evaluasi dan pengendalian maka rata - rata skor jawaban responden keseluruhan jenis UKM adalah 3,83 yang berarti peduli. Hal ini berarti responden mempunyai tingkat kepedulian yang tinggi akan pentingnya mencari penyebab penyimpangan dari standar dalam proses pengendalian. Namun, data yang muncul dari wawancara menunjukkan bahwa mayoritas UKM mempunyai sumber daya yang terbatas untuk melakukan hal tersebut sehingga mereka kebanyakannya belum melakukan upaya tersebut dan lebih memfokuskan sumber daya yang mereka miliki untuk mempertahankan pangsa pasar, menambah pelanggan, memperoleh dan meningkatkan kauntungan, sehingga pada akhirnya mereka akan tetap mampu bertahan dalam usaha mereka.

Selanjutnya untuk indikator menggunakan ukuran - ukuran kuantitatif dan kualitatif dalam proses pengendalian maka rata - rata skor jawaban responden keseluruhan jenis UKM adalah 4,06 yang berarti peduli. Hal ini berarti responden 
sebenarnya mempunyai tingkat kepedulian yang tinggi akan pentingnya menggunakan ukuran - ukuran kuantitatif dan kualitatif dalam proses pengendalian. Hasil wawancara menunjukkan juga bahwa mereka mempunyai kesadaran tinggi akan pentingnya ukuran-ukuran pengendalian tersebut. Namun,sama dengan indikator lainnya pada alinea di atas, para responden mendapatkan kendala karena mayoritasnya belum memahami bagaimana cara membuat ukuran - ukuran kualitatif dan kuantitatif tersebut, khususnya pada UKM yang pemiliknya hanya berpendidikan SMA ke bawah.

Kemudian untuk indikator menjadikan umpan balik untuk tindakan korektif dalam proses pengendalian maka rata - rata skor jawaban responden keseluruhan jenis UKM adalah 3,94 yang berarti peduli. Hal ini berarti responden mempunyai tingkat kepedulian yang tinggi akan pentingnya menjadikan umpan balik untuk tindakan korektif dalam proses pengendalian. Namun, hasil wawancara menunjukkan bahwa mereka melakukan hal tersebut belum secara tersistem dan hanya dilakukan sesekali jika diperlukan. Hal ini karena mereka mempunyai kendala keterbatasan SDM untuk melakukan evaluasi tersebut

Dengan demikian secara keseluruhan data pada tabel9 di atas menyimpulkan bahwa pemilik/pengelola UKM di Banyumas mempunyai kepedulian yang tinggi terkait dengan variabel proses pengendalian. Mereka mempunyai kesadaran yang tinggi akan pentingnya menjalankan item-item tersebut dalam proses evaluasi dan pengendalian namun masih terkendala oleh beberapa hal seperti yang dijelaskan pada alinea-alinea sebelumnya.

\section{KESIMPULAN, KETERBATASAN DAN SARAN}

\section{Kesimpulan}

Penelitian ini bertujuan mengevaluasi tingkat kesadaran para pemilik/pengelola UKM di Kabupaten Banyumas terhadap variabel-variabel sistem pengendalian manajemen yang meliputi perencanaan strategis, pengambilan keputusan, dan evaluasi dan pengendalian dengan menggunakan 55 pemilik UKM yang terdiri dari 20 UKM Toko, 18 UKM Rumah Makan, 12 UKM Pengolahan Produk Makanan, dan 5 UKM Batik di Kabupaten Banyumas. Data dari kuesioner berhasil mendokumentasikan bahwa pemilik/pengelola UKM di Kabupaten Banyumas sudah mempunyai kesadaran yang tinggi akan pentingnya penerapan variabel-variabel sistem penhgendalian manajemen yang mencakup perencanaan strategis, pengambilan keputusan, dan evaluasi dan pengendalian dalam mendukung usaha mereka.

Namun data yang diperoleh dari hasil wawancara menunjukkan bahwa umumnya UKM memiliki kendala untuk menerapkan variabel-variabel manajemen strategis dalam usaha mereka seperti tingkat pemahaman yang rendah khususnya bagi pemilik UKM dengan tingkat pendidikan SMA ke bawah dan terbatasnya sumber daya yang mereka miliki untuk mengerjakan hal tersebut. 
Dengan keterbatasan sumber daya yang mereka miliki maka pemilik UKM lebih memfokuskansumber daya untuk mempertahankan pangsa pasar, meningkatkan penjualan, dan mempertahankan usaha ditengah persaingan yang begitu ketat.

\section{Saran}

Dari temuan yang ada dalam penelitian ini bisa diberikan beberapa saran sebagai berikut:

1. Pemerintah bekerja sama dengan pihak ketiga seperti dari perguruan tinggi perlu memberikan pelatihan terkait dengan sistem pengendalian manajemen kepada pemilik/pengelola UKM dalam hal perencanaan strategis, pengambilan keputusan, dan evaluasi dan pengendalian sehingga bisa membantu meningkatkan pemahaman para pemilik/pengelola UKM akan hal-hal tersebut. Hal ini karena temuan dalam penelitian ini menunjukkan bahwa mereka sudah mempunyai kesadaran yang tinggi akan pentingnya variabel-variabel sistem pengendalian manajemen tersebut akan tetapi terkendala karena rendahnya pemahaman mereka untuk mempraktekkan hal tersebut. Perlu diberikan pelatihan dengan materi khusus seperti bagaimana membuat ukuran - ukuran kualitatif dan kuantitatif dalam proses pengendalian, menyusun biaya standar, merancang target usaha, mekanisme dalam pendelegasian tugas dan wewenang, manajemen konflik, menyusun perencanaan yang baik, dan sebaginya.

2. Dukungan lebih dari pemerintah daerah Kabupaten Banyumas harus diberikan kepada UKM dalam hal bantuan keuangan maupun non keuangan karena keterbatasan sumber daya yang mereka miliki sehingga UKM akan mampu menerapkan variabel - variabel sistem pengendalian manajemen dalam mengelola usaha mereka sehingga pada akhirnya UKM akan semakin tumbuh dan berkembang.

3. Penelitian ini merupakan miniriset yang mempunyai keterbatasn dalam hal jumlah responden dan rancangannya yang terbatas hanya melakukan analisis diskriptif dari kuesioner dan wawancara terbatas. Sehingga peneliti lain yang berminat melakukan penelitian dalam topik yang sama bisa lebih mengembangkan rancangan penelitiannya dan memperbesar ukuran sampelnya.

\section{REFERENSI}

Agustika, B.S., Auliyah, R., dan Herawai, N. 2015. Merajut Benang Merah Kesadaran Pelaku Usaha Mikro Dan Kecil terhadap Penyusunan Laporan Keuangan Dalam Mengakses Kredit Dana Bergulir. Prosiding SCA 5, Fakultas Ekonomi dan Bisnis Universitas Jenderal Soedirman. 
Anderson, D.R., Sweeney, D.J., Williams, T.A., Camm, J.D., and Cochran, J.J. 2016. Statistics for Business and Economics, $13^{\text {th }}$ Edition, South-Western College Pub.

Byrne, S. and Pierce, B. 2007. Towards a More Comprehensive Understanding of The Roles of Management Accountants. European Accounting Review, 16(3): 469-498.

DINKOPUKM Jawa Tengah. 2016. Time Series Data UMKM Binaan Provinsi Jawa Tengah, diunduh dari http://dinkop-umkm.jatengprov.go.id/ assets/upload/files/DATA\%20SERIES\%20UMKM\%20TW\%20IV\%20 2016.pdf

Ernawati, S., Asyikin, J., dan Sari, O. 2016. Penerapan Sistem Akuntansi Dasar pada Usaha Kecil Menengah di kota Banjarmasin. Jurnal Penelitian Ilmu Ekonomi WIGA, 6(2): 81-91.

Etikan, I., Musa., S.A,, and Alkassim, R.S. 2016. Comparison of Convenience Sampling and Purposive Sampling. American Journal of Theoretical and Applied Statistics, 5(1): 1-4.

Hopper, T., Koga, T., and Goto, J. 1999. Cost Accounting In Small And Medium Sized Japanese Companies: An Exploratory Study. Accounting and Business Research, 30: 73-86.

Horngren, C.T. 2014. Introduction to Management Accounting, $16^{\text {th }}$ Ed. Pearson Inc, USA.

Kurniawati, E.P., Nugroho, P.I., dan Arifin, C. 2012. Penerapan Akuntansi Pada Usaha Mikro Kecil dan Menengah (UMKM). Jurnal Manajemen Keuangan (JMK), 10(2): 1-10.

Otley, D. T. 1980. The Contingency Theory of Management Accounting: Achievement and Prognosis. Accounting, Organizations and Society, 5(4): 413-428.

Regondola, A. A. 2017. Awareness on Strategic Management Accounting of Small Medium-Sized Enterprises in the Kingdom of Bahrain.International Journal of Innovative Science, Engineering \& Technology, 4(5): 42-46.

Anthony, R.N., and Govindarajan, V. 2007. Management Control Systems, $12^{\text {th }}$ Edition, McGraw Hill.

Saragih, F., dan Surikayanti. 2015. Analisis Penerapan Akuntansi dan Kesesuaiannya Dengan SAK ETAP Pada UKM Medan Perjuangan. Prosiding Seminar Nasional Ekonomi, Manajemen dan Akuntansi, Fakultas Ekonomi dan Bisnis Universitas Negeri Padang: 452-461. 
Sullivan, G.M., and Artino-Jr, A.R. 2013. Analyzing and Interpreting Data From Likert-Type Scales. Journal of Graduate Medical Education, 5 (4): 541542.

Suyono, E. 2017. Peran Audit Ekternal Dalam Memajukan Usaha Kecil Dan Menengah Di Jawa Tengah: Sebuah Kajian Konseptual. Prosiding Seminar Nasional Muti Disiplin, UNISBANK 2017. Semarang.

Suyono, E., Farooque, O.A., \& Riswan, R. 2016. Toward a Model of Traditional Retailers and Sellers Empowerment in Improving Competitiveness Against Modern Markets in Banyumas Region, Indonesia. DLSU Business and Economics Review, 25(2): 147-165.

Wiedemann, D. 2014. Characteristics of Management Accounting In Small And Medium-Sized Enterprises. Case: Rantalinna Oy. Thesis Faculty of Business Administration, Saimaa University of Applied Sciences, Finlandia.

https://www.theseus.fi/bitstream/handle/10024/86259/Wiedemann_Daniel a.pdf? sequence $=1$. 